Article

\title{
Rushton and Jensen's Work has Parallels with Some Concepts of Race Awareness in Ancient Greece
}

\author{
Gabriel Andrade ${ }^{1, *}$ and Maria Campo Redondo ${ }^{2}$ \\ 1 Ajman University, Ajman 8723, UAE \\ 2 United Arab Emirates University, Al Ain 8765, UAE; mcampo@uaeu.ac.ae \\ * Correspondence: gabrielernesto2000@gmail.com
}

Received: 21 May 2019; Accepted: 14 June 2019; Published: 20 June 2019

\begin{abstract}
Rushton and Jensen's "Thirty Years of Research on Race Differences in Cognitive Ability" documents IQ differences in populations on the basis of race. The authors explain these data by arguing that cold winter conditions in Europe had greater pressure for the selection of higher intelligence. Critics of Rushton and Jensen, and of the very category of race, claim that race is a social construct that only came up in the 16th century, as a result of overseas voyages and the Atlantic slave trade. The goal of this article is to refute that particular claim, by documenting how, long before the 16th century, in classical antiquity race was already a meaningful concept, and how some Greek authors even developed ideas that bear some resemblance to Rushton and Jensen's theory. The article documents how ancient Egyptians already had keen awareness of race differences amongst various populations. Likewise, the article documents passages from the Hippocratic and Aristotelian corpus, which attests that already in antiquity, there was a conception that climatic differences had an influence on intelligence, and that these differences eventually become enshrined in fixed biological traits.
\end{abstract}

Keywords: Rushton; Jensen; race; classical antiquity; Greece

\section{Introduction: Rushton and Jensen's Landmark Work}

Rushton and Jensen's landmark article, "Thirty Years of Research on Race Differences in Cognitive Ability" [1] was an opportunity to bring together two different strains of research on intelligence into a unified coherent perspective.

Jensen's work focused on educational psychology, and he opened the way for a thorough discussion of academic achievements amongst different populations. His article "How Much Can We Boost IQ and School Achievement?" made the case that IQ tests are relevant inasmuch as they measure a general factor of intelligence, and that IQ test scores have a high degree of heritability [2]. Therefore, to his initial question, Jensen answered that, in fact, we cannot boost IQ and school achievement too much, because of genetic constraints. In turn, these theses lead to the conclusion that IQ differences between white and black populations have a strong genetic component, thus implying that the IQ differential (at least in the United States) between blacks and whites is not attributable (or at least not to a large degree) to racism and discrimination. This runs contrary to the prevailing environmentalist view in academia according to which the IQ achievement gap between blacks and whites is strictly due to non-genetic factors [3].

Predictably, the article aroused a great controversy, and Jensen was furiously (and sometimes viciously) attacked by egalitarians who opposed his views. For example, he received anonymous threats, and although nothing out of the ordinary happened, for a time he had to be escorted by personal bodyguards [4]. Yet, Jensen was hardly the first one to come up with these claims. Long before him, Spearman had already proposed the existence of a $g$ factor that underlies most intellectual skills, and that can be measured with IQ tests [5]. Likewise, Cyril Burt had done extensive research 
documenting the heritability of IQ, on the basis of twin studies [6]. Although these studies were severely criticized (even for their alleged fabrication of evidence and lack of transparency), they set the table for further research into the genetic bases of IQ. E vidence provided by Bouchard et al. on the basis of new twin studies, seems to make a much stronger case, [7] thus calculating the heritability of IQ to be 0.75 .

Murray and Herrnstein further expanded Jensen's thesis in The Bell Curve, providing extensive data supporting the claims that there is a significant achievement gap between blacks and whites, that this gap correlates well with IQ differences, and that IQ has a high component of heritability [8]. In the public view, The Bell Curve became the new object of discussion and criticism amongst egalitarians.

Yet, none of these researchers attempted to provide a deeper explanation as to why these IQ differences are found between blacks and whites. Murray and Herrnstein discuss the heritability of racial differences in IQ, but do not go into greater detail about the hypothetical evolutionary mechanism that causes these differences. Rushton's work, while not as widely discussed, did engage deeply in this question. Ruston was originally trained in psychology, but unlike Jensen, Murray and Herrnstein, he was far more interested in applying evolutionary theory to the understanding of race differences. Rushton proposed that in their evolutionary history, black and white populations developed different strategies that ultimately reflected their environmental locus of natural selection (whites in Europe, blacks in Africa), and he framed it in terms of $r-K$ theory.

As Rushton explains it, " $r$ is a term in Wilson's equation that stands for the amount of care parents give to ensure that their offspring survive. Plants and animals have different life history strategies. Some are more $r$ and others are more $K$. The $r$ and $K$ strategists differ in the number of eggs they produce. The r-strategists are like machine gunners. They fire so many shots that at least one of them will hit the target. The r-strategists produce many eggs and sperm, and mate and give birth often. The K-strategists give their offspring a lot of care. They work together in getting food and shelter, help their kin, and have complex social systems. That is why $K$-strategists need a more complex nervous system and a bigger brain, but produce fewer eggs and sperm" [9].

This has also been expressed in terms of "life history" (LH) theory, as articulated by Dutton and Madison. In their view, " ... a 'fast' LH strategy is characterized by having large numbers of offspring, but providing relatively little parental care. It tends to be observed in unstable ecologies in which it is beneficial to produce many offspring in order to ensure that at least some survive the unpredictable dangers, such as pathogens and predators, which lead to high mortality rates. Fast LH organisms live life fast and die young ... 'Slow' LH strategists have smaller numbers of offspring, but provide relatively high levels of parental care. They also tend to mature more slowly and live longer than fast LH strategists. A slow LH strategy tends to be observed in more stable ecologies" [10]. Dutton and Madison expand this approach, by including measures such as puberty length, pubic hair, and menstruation, all of which vary by race.

Rushton agreed that humans are decidedly on the $K$ side, but if the human species is divided by races, whites are even more inclined than blacks towards the $K$ side. Rushton believed that ecological conditions explain this. European climates, with harsh cold winters, did not provide resources that could afford large numbers of offspring. Likewise, there was stronger pressure for intelligence to be selected, given that survival in those harsh conditions required humans to have a greater degree of intelligence. By the same token, African environmental conditions provided greater resources (thus not having as strong a pressure for intelligence), but added viral and bacterial threats to populations, thus creating a stronger pressure for selecting sexual features and behaviors that generate a greater number of offspring.

In "Thirty Years of Research on Race Differences in Cognitive Ability", Rushton and Jensen further elaborate Rushton's initial theory, and explain it in clear terms: "Evolutionary selection pressures were different in the hot savanna where Africans lived than in the cold northern regions Europeans experienced ... These ecological differences affected not only morphology but also behavior. It has been proposed that the farther north the populations migrated out of Africa, the more they encountered 
the cognitively demanding problems of gathering and storing food, gaining shelter, making clothes, and raising children successfully during prolonged winters ... As these populations evolved into present-day Europeans and East Asians, the ecological pressures selected for larger brains, slower rates of maturation, and lower levels of testosterone-with concomitant reductions in sexual potency, aggressiveness, and impulsivity; increases in family stability, advanced planning, self-control, rule following, and longevity" [1] (pp. 265-266).

In "Thirty Years of Research on Race Differences in Cognitive Ability", Rushton and Jensen present data that document how, as a general trend, when compared with Africans, Europeans have on average greater cognitive ability and brain size. As they report it, “ ... using the head circumference measures to calculate cranial capacity at birth, 4 months, 1 year, and 7 years, at each of these ages, the Asian American children averaged larger cranial volumes than did the White children, who averaged larger cranial volumes than did the Black children. Within each race, cranial capacity correlated with IQ scores. By age 7, the Asian American children averaged an IQ of 110; the White children, 102; and the Black children 90. Because the Asian American children were the shortest in stature and the lightest in weight while the Black children were the tallest in stature and the heaviest in weight, these average race differences in brain-size/IQ relations were not due to body size" [1] (p. 254). This information is gathered on the basis of transracial adoption studies, racial admixture studies, and other methods. In the same manner, Rushton and Jensen sought to explore how related LH traits play a role, and this supports Rushton's previous findings that, in concordance with his $r-K$ theory, Africans have increased sexual activity, AIDS prevalence, and births with twins. The article is a joint effort that focuses on intellectual achievement and brain size, but engages in a significant effort to try to prove that what the authors call the "culture-only" model of the causes of mean black-white differences is deficient, whereas the data for a genetic explanation of this gap is strong.

\section{One Particular Strand of Criticism}

"Thirty Years of Research on Race Differences in Cognitive Ability" has been criticized on many fronts, and so have Jensen's and Rushton's individual works. These criticisms have elicited extensive discussions, and for the purposes of this article, we shall not be concerned with them. Likewise, we shall not be concerned with whether Rushton and Jensen's main thesis (i.e., the refuting of the "culture-only" model for the black-white IQ gap) is the correct one. For now, it suffices to say that some critics claim that data recollection for the article was not accurate, and that the authors may have rushed to conclusions, not considering other environmental variables [11]. However, this criticism has been sufficiently rebutted with more robust data, provided by other studies that confirm Rushton and Jensen's original arguments [12]. Furthermore, it should be noted that other studies have also added significant weight to the argument that the selective pressures of particular historical developments have also contributed to changes in IQ differences amongst populations. The development of agriculture is traditionally considered to be too recent to account for any meaningful change in the gene pool influencing IQ heritability, but Cochran and Harpending adequately show the influence of this particular momentous event on race differences [13]. More recently, science journalist Angela Saini has addressed popular audiences with Superior [14], a book presenting the typical arguments against race as a concept (e.g., races are ill-defined, etc.); however, as Winegard and Carl point out in their review of the book, [15] Saini's arguments are sloppy, and they confuse what races actually are (if properly defined, then it becomes clear that divisions are not arbitrary, and race remains a useful concept).

However, we shall be concerned with a secondary criticism that is frequently leveled, not only against Rushton and Jensen's article, but against all research programs and treatises that aim to affirm racial differences, both physical and behavioral. This criticism basically holds that race is a social construct. For example, in a widely used textbook by students of Sociology and Ethnic Studies in the United States, the authors claim that "while there is a link between biology and the social racial disparities that should not be lost, race is ultimately a powerful social construct, with both social and biological consequences, and not a biological reality" [16]. 
If this particular viewpoint were true, then Rushton and Jensen's work would be demolished, because the reality of race is the very foundation of their work. Rushton and Jensen are fully aware of this, but have a reply: "Some have argued that the cause of Black-White differences in IQ is a pseudo question because 'race' and 'IQ' are arbitrary social constructs ... However, we believe these constructs are meaningful because the empirical findings in this article have been confirmed across cultures and methodologies for decades" [1].

While upholders of the view that race is a social construct may have some arguments in their favor [17], stronger evidence suggests that race is not a social construct. This assessment can be made on the basis of both anatomical and genetic evidence [18]. At any rate, proponents of race as a social construct are wrong to advance one particular historical argument to support their case. They hope to refute the existence of race by attempting to explain why people came to believe in race in the first place. This argument actually forms part of a postmodernist trend in philosophy. Authors such as Nietzsche and Foucault [19] believed that if they could uncover the hidden origins of a particular belief, that belief would be refuted, and this approach is put at play to advance this particular argument.

The argument is based on the historical claim that, inasmuch as race is a social construct, it reflects specific social and cultural circumstances that gave rise to the idea that races are real biological entities. In this standard narrative, affirmation of racial differences is a relatively recent thing, only going back to the 16th century. Two particular historical developments propitiated the appearance of the segmentation of humanity on the basis of racial traits, overseas exploration and the Atlantic slave trade.

In the words of anthropologist C. Loring Brace: "In the 1400s, traveling by foot or camelback, it never occurred to even the most seasoned world travelers to categorize people, because what they saw was gradual variation ... For Europeans, that changed in the 1500s and 1600s, when you could get into a boat, sail for months, and wind up on a different continent. When you got off, wow, did everybody look different! Our traditional racial groupings are simply the end points of the old trans-oceanic trade networks" [20]. This argument is not well supported by evidence. Cavalli-Sforza, for example, has conclusively shown that genetic clusters can be neatly separated, and that they correspond well to racial differences, thus refuting the claim that this way of organizing human biodiversity only reflects the perceptions of interoceanic travel [21].

Likewise, according to this argument, slavery played a pivotal role in the origin of racial thinking. For economic reasons, by the end of the Middle Ages, Europeans were not enslaving other Europeans anymore. The greatest supply of slaves now came from Africa. As analyzed by Marxist historians, in order to sustain the morality of the brutality of slavery in the face of ethical progress, slaveholders began to speak about innate racial differences between blacks and whites, which ultimately justified why blacks could be enslaved. In that manner, historian George Fredrickson explains: "The fact that Europeans were ceasing to enslave other Europeans at the time when African slaves became suddenly and readily available was at the root of white supremacist attitudes and policies" [22] renowned Marxist historian C.L.R. James agrees: “ . . historically it is pretty well proved now that the ancient Greeks and Romans knew nothing about race ... the conception of dividing people by race begins with the slave trade" [23].

This was further reinforced under the encyclopedist trend of the Enlightenment, with its great fondness for classification. Thus, authors such as Hume and Kant emphasized racial differences amongst human beings.

Consequently, defenders of the idea that race is a social construct typically hold that race is a concept with a surprisingly short history. In fact, they are keen to argue that race did not exist as a meaningful idea prior to the 16th century, and was decidedly absent in antiquity. In this account, Greek and Roman civilizations were certainly xenophobic, but this xenophobia was never expressed in racial (i.e., biological) terms.

Therefore, this reasoning typically attempts to prove that views such as the ones advanced by Ruston and Jensen in their article, are contingent on particular social and cultural circumstances of the last five centuries, and that were it not for the dramatic transformations of the Age of Exploration and 
the Atlantic slave trade, such views would have never been advanced. However, if it were found that Rushton and Jensen's views do have some historical antecedents in the epochs that antecede both the Age of Exploration and the Atlantic slave trade, then this particular criticism would be refuted.

As it happens, in Ancient Greece there were indeed views that bear some resemblance to formulations of race concepts, and Rushton and Jensen's theses. First, contrary to conventional wisdom, it seems that Greeks, Egyptians and Romans had greater awareness of racial differences than what conventional historians are prepared to admit.

But, especially in the civilizations of classical antiquity, this racial awareness was also complementary of a type of ecological determinism that finds some resonance especially in Rushton's work.

Ecological determinism is the view that the conditions of specific geographic environments account for significant differences in behavioral traits amongst populations. This is an intellectual tradition with an extensive history, including prominent figures such as Montesquieu. More recently and most influentially, Jared Diamond has advanced the thesis that Western dominance in recent world history is not because of higher IQ in European populations (Diamond believes IQ is meaningless), but rather, because of ecological advantages such as a West-East axis and the availability of plants and animals for domestication [24].

Rushton and Jensen's work does not belong to this type of ecological determinism. In "Thirty Years of Research on Race Differences in Cognitive Ability", the authors document that blacks and whites have different IQ and achievement levels in the United States. Therefore, even under the same geographical conditions, the gap persists. In Rushton and Jensen's view, this suggests that race (on the basis of genetics), and not mere geographic conditions, account for the gap. If the gap is rooted in genetics, then a change of geographic environment is not going to modify the gap to a great extent, because genes are fixed.

Furthermore, sympathizers of Rushton and Jensen's views have explicitly criticized Diamond's theses. For example, Michael Hart argues that, compared to Mesoamerica, Africa had more of the advantageous environmental conditions that Diamonds considers, yet Mesoamerica achieved higher levels of civilizational development, thus suggesting (according to Hart's conclusion) that this particular gap goes deeper than geography, and is perhaps determined by genes. Consider Hart's own assessment of Diamond's work: “By 1000 AD, Mesoamerica was far more advanced than SSA [sub-Saharan Africa] was, or ever had been. For example, Mesoamericans had originated writing on their own, had constructed many large stone structures, and had built large cities (rivaling any existing in Europe, and far larger than any in sub-Saharan Africa). Furthermore, the Mayan achievements in mathematics and astronomy dwarf any intellectual achievements in SSA. We must therefore conclude that, although Guns, Germs, and Steel [Diamond's main book] is an informative book, the obvious superiority of Mesoamerican technology to that of sub-Saharan Africa appears to be a fatal blow to the main arguments presented in it ... Of course, even if Dr. Diamond had demonstrated that the backwardness of SSA could be completely explained by geographic factors, that would still not prove there is no genetic component to the observed difference in mean IQ between blacks and whites" [25].

Yet, even if Rushton and Jensen's theory does not belong to the geographic determinist school in the same sense as Diamond's theses, on a deeper level, it does rely on a form of geographic determinism. For, the way Rushton and Jensen explain the evolutionary origins of genetic differences between European and African populations does ultimately extend back to the differences between European and African geographic conditions. Recall that, in their theory, Europe's harsh winters and lack of food availability pressured for an evolutionary strategy that leaned towards $r$, and this implies higher degrees of intelligence.

Prominent authors from classical antiquity had geographic determinist views of the conventional type (i.e., similar to those of Montesquieu, Diamond, etc., in modern times). But they also appeared to have some intuitive understanding that was closer to Rushton and Jensen's ecological determinism, for the way they wrote about differences amongst populations was very much reminiscent of race, 
with fixed attributes grounded in biology. This is not to say that Greek authors anticipated Rushton and Jensen's views in every detail, to assume so would be a major distortion. But the case can be made that some classical authors did have concepts of race awareness and linked these with some notions of geographic determinism and heredity. Therefore, our main research question shall be: Can we find some notions of race awareness (and some similarities to Rushton and Jensen's work) in some authors of classical Greece? As we shall see, the answer is "yes".

This will not prove that Rushton and Jensen are right in their claims, or even that race is not a social construct. But it will prove that the concept of race did not appear as a result of slavery and overseas voyages, and thus, Rushton and Jensen's work can at least be defended against those critics who seek to deconstruct their theses on the basis of the alleged historical origins of their views. Classical antiquity is typically defined as the historical period between the 8th century BC and the 6th century AD, during which civilizations flourished in the Mediterranean area. Although there were many of these civilizations, their matrix has always been Greek civilization, with occasional loans from surrounding civilizations such as the Egyptians, the Ethiopians, etc. The Western intellectual tradition has always looked up to the Greeks to discuss its own historical roots. And this also applies to discussions regarding the history of the awareness of race differences. Consequently, in the following sections, we shall discuss how the Greeks understood racial differences and the effects of climatic differences on behavioral traits. Admittedly, many other civilizations of the past (Persians, Chinese, Moors, etc.) have had their own concepts of racial differences, but that is beyond the scope of the present article. In order to refute the claim that race as a concept only came about with historical events of the 16th century, it suffices to focus on the one civilization that has had the greatest influence on the Western world, ancient Greece.

\section{Egyptian Awareness of Race}

Greek authors also had curiosity about Egyptian life, and many Greek writings took inspiration from them. In that sense, consideration of Egyptian awareness of racial differences are an important aspect to further understand the Greek approach to human biodiversity.

In the 1990s there was a major academic controversy over Afrocentrism. This was a movement that sought to teach a peculiar version of History. Afrocentrists made two central claims: (1) Ancient Greeks stole arts and philosophy from the Egyptians, (2) ancient Egyptians were black. Afrocentrists claimed there was a conspiracy orchestrated by whites in order to keep these facts hidden.

Both claims are extremely dubious, and they have been duly and carefully debunked by Mary Lefkowitz in Not Out of Africa [26]. Yet, in her refutation, Lefkowitz accuses Afrocentrists of projecting their own racial concerns on the Egyptians, when in fact, Egyptians paid little (if any) attention to race differences.

There are some reasons to doubt this. It seems quite straight-forward that Egyptians, as well as their neighbors in antiquity, had something very similar to our modern concept of race. We know from pictorial evidence that Egyptians continuously differentiated between other nations and themselves, and in order to do so, they very consciously used different colors. Lefkowitz acknowledges this, but seems unsure as to whether or not these were racial distinctions: "Egyptians made clear distinctions between themselves and other peoples, which they represented in their art. Wall paintings are not photographs, and to some extent the different colors may have been chosen as a means of marking nationality, like uniforms in a football game. The Egyptians depicted themselves with a russet color, Asiatics in a paler yellow. Southern peoples were darker, either chocolate brown or black" [27].

It is naïve to believe that when Egyptians chose dark colors to represent Southern peoples, they were merely a sort of football uniform. It seems more likely that dark colors were chosen because, well, Nubians (Egypt's neighbors to the South) were very dark indeed. Further proof that these depictions were not analogous to mere football uniforms is that there are representations in which Nubians are depicted not only as having darker colors, but also having flat noses and thick lips [28]. 
We also know that ancient Egyptian literature was concerned with racial differences. It is true that the ancient world, and most especially various peoples in the Near East (including the Israelites) commonly segmented nations fundamentally in linguistic terms, but one particular Egyptian poem, the Great Hymn to Aten, praises a deity, and as part of that, along with mentioning languages as a way to distinguish nations ("their tongues are separate in speech"), also exalts: "Their skins are distinguished" [29]. Clearly, Egyptians were concerned with differences of skin colors amongst different peoples.

\section{Greek Awareness of Race}

The Greeks seemed to be equally conscious. They were curious about Africans' darker skin color, and the designation for them reflects this very well. Aethiops (the basis for Aethiopia) means "burned face", and the Greeks even had a myth to explain why Ethiopians had darker skin: Phaethon rode the sun with his chariot, and on the journey, came too close to the land of the Ethiopians, thus burning their faces.

Aesop seemed to be particularly interested in Ethiopians' skin color as an illustration for one of his many moral lessons. In one of his fables, a slave owner tries to wash away the dark skin color of a black slave (thinking that the previous owner had neglected to keep the slave clean), only to realize that it is impossible. The obvious message of the fable is that some things just cannot be changed, but we must not lose sight of the racial undertone: Aesop did seem to believe that there are some inherent racial characteristics that define particular groups of people, and that they are fixed. In fact, although as previously mentioned, the Israelites were much more concerned with linguistic differences, one Biblical author did express a similar view to Aesop's: "Can the Ethiopian change his skin or the leopard his spots? [Implying "no", of course]" (Jeremiah 13:23).

As the example of the Ethiopian shows, authors in antiquity seemed to be aware that many physical qualities are hereditary, and in that sense, they came close to a modern understanding of race. However, they did not fully claim that these hereditary traits correlate with different mental characteristics.

Some authors tried to find less mythical and more rational explanations as to why particular populations look different. Again, blacks aroused some interest in this regard. For example, in Problems, Aristotle (or perhaps another author who wrote in his name) wonders: "Why are the Ethiopians and the Egyptians bandy-legged? Is it because bodies of living creatures become distressed by heat, like logs of wood when they become dry? The condition of hair too supports this theory; for it is curlier than that of other nations, and curliness is as it were crookedness of hair" [30]. Needless to say, no modern evolutionary biologist would give credit to this theory, but for our purposes, it serves to illustrate that this particular author believed that populations differ in their physical traits according to the climate they inhabit, and this is one aspect of racial thinking. In fact, modern evolutionary biologists do take seriously Bergman and Allen's rule [31] which states that biogeographical conditions have great influence on the body shape of species and subspecies.

Greek authors were keen to categorize populations in terms of differences between groups. This is another feature of racial thinking. Of course, contemporary authors such as Rushton and Jensen have never proposed group-based discrimination, as persons should be evaluated on the basis of their own individual merits. Rushton and Jensen are likewise quite aware that even within groups, there are differences: "Of course, in referring to population or racial group differences we are discussing averages. Individuals are individuals, and the three groups [blacks, whites and Asians] overlap substantially on almost all traits and measures" [1] (p. 238). But Rushton and Jensen do believe that, as a whole, members of particular racial groups preserve some degree of homogeneity that permits cross-group comparisons, and that is why they believe that race is a meaningful concept.

Many Greek authors would have agreed. For example, the text On Airs, Waters and Places (allegedly written by Hippocrates, although this is doubtful) describes Scythians and Egyptians as follows: "In respect of the seasons and the figure of the body, the Scythian race, like the Egyptian, have a uniformity of resemblance, different from all other nations ... their shapes resemble one another, 
the males being all alike, and also with the women" [32]. The same text describes the homogeneity of Asians (not people of East Asia, as Rushton and Jensen may understand them, but rather natives from the eastern shore of the Aegean sea): "[They] are well fed, most beautiful in shape, of large stature, and differ little from one another as to either figure or size" [33]. Again, it is clear here that the author believes that, for particular physical traits, there is within group homogeneity, but inter-group differences are significant. This is an important feature of race as a concept.

Historian Benjamin Isaac's assessment of this text is notorious: " $\ldots$ it seems to be the first work in Greek literature, or any literature for that matter, which consistently describes peoples in terms of stereotypes that are said to cover all of the individual groups it describes. It leaves no room for any individuality" [34].

We can thus be assured that race was not an alien concept to people in antiquity, and that long before the Age of Exploration and racial slavery, people were already thinking in terms of racial groups. However, this does not necessarily imply that civilizations in classical antiquity established natural hierarchies on the basis of racial traits. Renowned historian Frank Snowden acknowledges that Greeks and Romans were fully aware of racial differences. But, according to him, "nothing comparable to the virulent color prejudice found in modern times existed in the ancient world black skin color was not a sign of inferiority, Greeks and Romans did not establish color as an obstacle to integration of society; and ancient society was one that, for all its faults and failures, never made color the basis for judging a man" [35].

There is little to dispute in Snowden's assessment, as he demonstrates sufficiently well that people of many races excelled in civilizations of classical antiquity. Yet, we can still explore the way Greek authors conceptualized racial hierarchies. These conceptualizations do differ from modern ideas, in the sense that conventional racial traits (skin color, head shape, etc.), or even other traits such as the ones studied by Rushton and Jensen (brain size, maturation rate, hormones, etc.), were not relevant. Yet, authors in antiquity did believe that particular physical traits, ultimately caused by geographical factors, did account for differences in behavior amongst populations.

\section{Greek Authors and Theories of Environmental Determinism}

There was a very prominent tradition of ecological determinism amongst Greek authors. At first sight, this ecological determinism was actually the opposite of Rushton and Jensen's theory. Recall that according to this theory, the harsh conditions of European winters were a selective pressure for greater intelligence; as Richard Lynn further explains it: "The colder the winters, the stronger this selection pressure: this was the mechanism through which higher intelligence evolved. This explains the broad association between latitude- or more precisely, the coldness of winter temperatures-and the intelligence of races" [36].

Aristotle believed that populations in countries that are too cold are actually less intelligent: "The peoples of cold countries generally, and particularly those of Europe, are full of spirit, but deficient in skill and intelligence; and this is why they continue to remain comparatively free, but attain no political development and show no capacity for governing others. The peoples of Asia are endowed with skill and intelligence, but are deficient in spirit; and this is the way they continue to be peoples of subjects and slaves. The Greek stock, intermediate in geographical position, unites the qualities of both sets of peoples. It possesses both spirit and intelligence: the one quality that makes it continue to be free" [37].

This particular passage is typical of Greek ethnocentrism that considered other peoples barbarians (on the basis of their alleged inability to speak), and considered that Greeks were the best in every regard. In Aristotle's case, this fondness for peoples (the Greek) who inhabit temperate climates (neither too cold nor too hot) may reflect his own inclination towards moderation and balance, as in his ethical doctrine of the virtuous middle.

But, apart from Aristotle, other authors made similar ethnocentric statements regarding the idealness of Greek climate. Herodotus, for example, says that "Greece has been given a climate more beautiful tempered (than any other country)" [38]. Plato says that Athena chose the location for her 
city, because it has "a temperate climate throughout the seasons which would bring forth men of surpassing wisdom" [39]. In this regard, the ethnocentrism of these Greek authors is very far removed from Rushton and Jensen, who claim that East Asians actually have higher IQ than whites (the group to which both Rushton and Jensen belong).

Yet, in other important aspects, the geographic determinism of some Greek authors actually resonates with Rushton and Jensen's theory. Admittedly, it was claimed in antiquity that populations in colder countries have lower intelligence, but at the same time, it was argued that when geographic conditions are too pleasing to populations, these populations do not thrive. For example, Herodotus mentions that "the sea and mountains of Greece, the poverty of her soil, and the isolation of her valleys, made her not only the home of liberty but the nursery of heroes" [34] (p. 57).

This particular thought resonates with Rushton and Jensen's theory, in the sense that the degree of intellectual excellence in a given population is correlated with the harshness of its ecological location. The Cyropaedia had a similar proposition. In Isaac's interpretation of this particular text, "the physical, spiritual and moral qualities of the inhabitants of Asia are all determined by the climate in which they live. The paradox is that the climate is fine, nature prolific, the people are therefore well off- and the result is that they are feeble" [34] (p. 63).

All these comments from Classical authors amount to a form of geographic determinism, according to which climates ultimately determine the behavior of particular groups. In these descriptions, the authors do not make explicit references to how those geographic conditions may actually cause the racial differences of which they were aware. In that regard, authors in classical antiquity seem to resemble Rushton and Jensen's theory less, and the theories of, say, Jared Diamond more, who appeals extensively to geographic factors, but never to racial factors grounded in genetics.

However, although not necessarily in an explicit manner, some Greek authors considered that geographic conditions do account for changes in the racial nature of populations, and this is permanently enshrined in their stock. This view is closer to Rushton and Jensen's thesis. In Rushton and Jensen's thesis, cold European climates pressured for higher intelligence in European populations; however, because this operates on the basis of natural selection, higher intelligence remains coded in the genes. So, although climate is the ultimate causal factor for differences in intelligence, changes in climate will not in the short term alter the behavior of populations. This would explain, for example, why whites still have higher IQ in tropical countries, whereas blacks remain with lower IQ in cold countries.

Authors in Classical Greece likewise believed that even if groups of people moved from one country to another, their behavior would not significantly change over the generations. They believed this because, just as much as Rushton and Jensen do, they considered that differences in populations were fixed in their very nature, and were not purely contingent on climatic differences. Although Snowden is right to claim that blacks were, for the most part, successfully assimilated into Greek and Roman society, classical authors still believed that a person coming from a hot climate would behave as people from hot climates do, even if they now lived in a temperate climate.

Yet, instead of providing a Darwinian explanation (as in the case of Rushton and Jensen), they provided an explanation that we may very well call Lamarckian. Greek authors to a large extent believed that acquired characteristics were inherited. For example, the text On Airs, Waters and Places considers the people of Trapezus, who had the custom of artificially elongating their children's heads. The author of this text believed that this particular practice would make elongated heads in the future generations, without parents having to artificially do the procedure: "Thus, at first, usage operated, so that this constitution was the result of force: but, in the course of time, it was formed naturally; so that usage had nothing to do with it ... If, then, children with bald heads are born to parents with bald heads; and children with blue eyes to parents who have blue eyes; and if the children of parents having distorted eyes squint also for the most part; and if the same may be said of other forms of the body, what is to prevent it from happening that a child with a long head should be produced by a parent having a long head?" [40]. Aristotle had similar ideas: "Mutilated young are born of mutilated parents" [41]. 
The logical conclusion of this reasoning is that if a particular climate makes a population intelligent, then offspring in the future generations will already be born intelligent. But this theory should also lead to the conclusion that when populations migrate from one climate to another, with the passing of a few generations, their nature must change, because the environmental conditions have changed, and the migrating population becomes similar to the other populations in that same territory. Yet, authors in antiquity did not come to this conclusion in full terms. They seemed to believe that only negative traits were inherited (such as long heads or scars, as in the texts quoted above). Isaac explains the theoretical framework as follows: "This corresponds well with the general absence, in antiquity, in a belief in progress and improvement over time. Change can only be for the worse" [34] (p. 79). In consequence, a group from a given climate may migrate to another climate and as a result end up with lower intelligence; however, a group cannot increase its intelligence by migrating to another climate, because their intelligence somehow remains fixed.

Authors in classical antiquity seemed to have some intuitive notion that in some cases, particular traits (including intelligence) remain fixed and cannot be changed, very much as Aesop's fable of the Ethiopian suggests. They were far from understanding concepts of natural selection, but they did seem to have some intuitive (if rudimentary) grasp that climates in the very long term may change a population's genetic constitution, but not in the short term.

\section{Conclusions}

Societies of the classical world were not colorblind. For them, race was a meaningful concept. Although by no means the sole category to divide the world, race was still used by the Greeks to establish differences amongst people. These categorizations did not necessarily manifest themselves in prejudices, but racial categorizations did exist.

Ancient authors may or may not have been right in using race as a meaningful concept; that debate is beyond the scope of this article. But it is certainly a fact that Greek authors did have strong intuitions towards race categorizations, although intuitions are not necessarily reliable. The fact that people in the classical world thought in terms of race does not prove that racial thinking is inherent to the human species, or that race is not a social construct. However, it does prove that those historians eager to claim that racial thinking only emerged after the 16th century due to slavery and overseas voyages, are wrong. As we have discussed in this article, long before Christopher Columbus, authors such as Aristotle, Herodotus, Hippocrates and others, had some intuitive ideas that maintain some resemblance to the theories of Rushton and Jensen, perhaps the most important theoreticians of race differences in the 21st century.

Author Contributions: Conceptualization, G.A. and M.C.R.; methodology, G.A. and M.C.R.; software, G.A. and M.C.R.; validation, G.A. and M.C.R.; formal analysis, G.A. and M.C.R.; investigation, G.A. and M.C.R.; resources, G.A. and M.C.R.; data curation, G.A. and M.C.R.; writing-original draft preparation, G.A. and M.C.R.; writing-review and editing, G.A. and M.C.R.; visualization, G.A. and M.C.R.; supervision, G.A. and M.C.R.; project administration, G.A. and M.C.R.; funding acquisition, G.A. and M.C.R.

Funding: This research received no external funding.

Conflicts of Interest: The authors declare no conflict of interest.

\section{References}

1. Rushton, J.; Jensen, A. Thirty Years of Research on Race Differences in Cognitive Ability. Psychol. Public Policy Law 2005, 11, 235-294. [CrossRef]

2. Jensen, A. How Much can We Boost IQ and School Achievement. Harv. Educ. Rev. 1969, 39, 1-123. [CrossRef]

3. Miranda, M.; Dohyeong, K.; Reiter, J.; Overstreet, A.; Maxson, P. Environmental Contributors to the Achievement Gap. Neutotoxicology 2009, 30, 6. [CrossRef] [PubMed]

4. Meisenberg, G. God's Image: The Natural History of Intelligence and Ethics; New York Book Guild: New York, NY, USA, 2007; p. 245. 
5. Spearman, C. General intelligence, objectively determined and measured. Am. J. Psychol. 1904, 15, $201-293$. [CrossRef]

6. Fletcher, R. Science, Ideology, and the Media: The Cyril Burt Scandal; Transaction: New York, NY, USA, 2013.

7. Bouchard, T.; Lykken, M.; Segal, N.; Tellegen, A. Sources of Human Psychological Differences: The Minnesota Study of Twins Reared Apart. Science 1990, 250, 223-228. [CrossRef] [PubMed]

8. Herrnstein, R.; Murray, C. The Bell Curve: Intelligence and Class Structure in American Life; Free Press: New York, NY, USA, 1994.

9. Rushton, J. Race, Evolution and Behavior: A Life History Perspective; Charles Darwin Institute: Port Huron, MI, USA, 2000; p. 34.

10. Dutton, E.; Madison, G. Life History and Race Differences in Puberty Length: A Test of Differential-K Theory. Mank. Q. 2016, 56, 546.

11. Cernovsky, Z. A Critical Look at Intelligence Research. In Critical Psychology: An Introduction; Fox, D., Prilleltensky, I., Eds.; Sage: London, UK, 2001; p. 132.

12. Lynn, R. Reflections on Sixty-Eight Years of Research on Race and Intelligence. Psych 2019, 1, $123-131$. [CrossRef]

13. Cochran, C.; Harpending, H. The 10,000 Year Explosion: How Civilization Accelerated Human Evolution; Basic: New York, NY, USA, 2009.

14. Saini, A. Superior. The Return of Race Science; Beacon: Boston, MA, USA, 2019.

15. Winegard, B.; Carl, N. Superior. The Return of Racial Science-A Review. Quillette. 2019. Available online: https:/quillette.com/2019/06/05/superior-the-return-of-race-science-a-review/ (accessed on 15 June 2019).

16. Goodman, A.; Moses, Y.; Jones, J. Race: Are So Different? Wiley \& Blackwell: Oxford, UK, 2012; p. 232.

17. Harrison, G. Race and Reality: What Everyone Should Know about Our Biological Diversity; Prometheus: New York, NY, USA, 2010.

18. Salter, F. On Genetic Interests; Transactions: New York, NY, USA, 2006.

19. Mahon, M. Foucault's Nietzschean Genealogy: Truth, Power, and the Subject; State University of New York Press: New York, NY, USA, 1992.

20. Goodman, A.; Moses, Y.; Jones, J. Race; Wiley-Blackwell: Hoboken, NJ, USA, 2012; p. 17.

21. Cavalli-Sforza, L.L. The Genetics of Human Populations; Dover: New York, NY, USA, 2013.

22. Fredrickson, G. Racism: A Short History; Princeton University Press: Princeton, NJ, USA, 2002; pp. $28-29$.

23. James, C. Modern Politics; PM Press: Chicago, IL, USA, 2013; p. 127.

24. Diamond, J. Guns, Germs and Steel; W.W. Norton: New York, NY, USA, 1997.

25. Hart, M. Understanding Human History; Washington Summit Publishers: Augusta, GA, USA, 2007; pp. $176-177$.

26. Lefkowitz, M. Not Out of Africa: How "Afrocentrism" Became an Excuse To Teach Myth As History; Basic: New York, NY, USA, 1996.

27. Lefkowitz, M. History A Race Odyssey Lesson; Yale University Press: New Haven, CT, USA, 2008; p. 39.

28. Sarich, V.; Miele, F. Race: The Reality of Human Differences; Westview: New York, NY, USA, 2004; p. 34.

29. Wilson, J.A., Translator; The Great Hymn to Athen. Available online: https://katherinestange.com/egypt/ hymn2.htm (accessed on 15 June 2019).

30. Aristotle. Problems, 909a 1. Available online: https://www.loebclassics.com/view/aristotle-problems/2011/ pb_LCL317.275.xml (accessed on 15 June 2019).

31. Sharma, R.; Rajendra, S. Anthropology; Atlantic: New Delhi, India, 1997; p. 53.

32. On Airs, Waters and Places, 19. Available online: http://classics.mit.edu/Hippocrates/airwatpl.19.19.html (accessed on 15 June 2019).

33. On Airs, Waters and Places, 12. Available online: http://classics.mit.edu/Hippocrates/airwatpl.12.12.html (accessed on 15 June 2019).

34. Isaac, B. The Invention of Racism in Classical Antiquity; Princeton University Press: Princeton, NJ, USA, 2004; pp. 57-79.

35. Snowden, F. Before Color Prejudice: The Ancient View of Blacks; Harvard University Press: Cambridge, MA, USA, 1983; p. 63.

36. Lynn, R. Race Differences in Intelligence: An Evolutionary Analysis; Washington Summit Publishers: Augusta, GA, USA, 2006.

37. Aristotle. Politics, 1327b. Available online: http://classics.mit.edu/Aristotle/politics.html (accessed on 15 June 2019). 
38. Herodotus. History, 3.106. Available online: http://classics.mit.edu/Herodotus/history.html (accessed on 15 June 2019).

39. Plato. Timaeus, 24c. Available online: http://classics.mit.edu/Plato/timaeus.html (accessed on 15 June 2019).

40. On Airs, Waters and Places, 14. Available online: http://classics.mit.edu/Hippocrates/airwatpl.14.14.html (accessed on 15 June 2019).

41. Aristotle. On the Generation of Animals, 721b. Available online: https://archive.org/details/ worksofaristotle512aris/page/n357 (accessed on 15 June 2019).

(C) 2019 by the authors. Licensee MDPI, Basel, Switzerland. This article is an open access article distributed under the terms and conditions of the Creative Commons Attribution (CC BY) license (http://creativecommons.org/licenses/by/4.0/). 